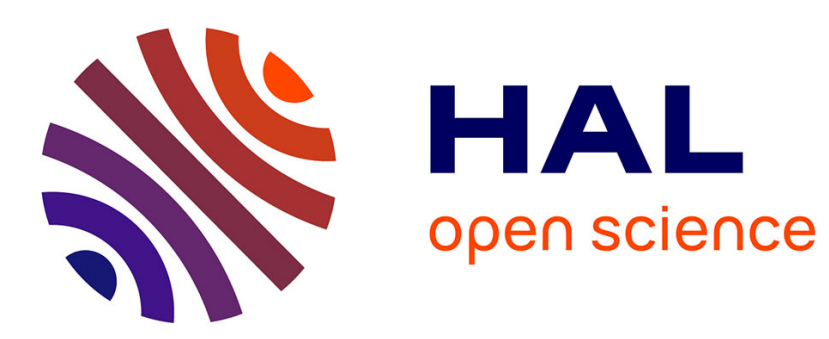

\title{
Caldera rim collapse: A hidden volcanic hazard
}

Olivier Merle, Laurent Michon, Patrick Bachèlery

\section{To cite this version:}

Olivier Merle, Laurent Michon, Patrick Bachèlery. Caldera rim collapse: A hidden volcanic hazard. Journal of Volcanology and Geothermal Research, 2008, 177 (2), pp.525-530. 10.1016/j.jvolgeores.2008.06.011 . hal-00373485

\section{HAL Id: hal-00373485 \\ https://hal.science/hal-00373485}

Submitted on 24 Oct 2016

HAL is a multi-disciplinary open access archive for the deposit and dissemination of scientific research documents, whether they are published or not. The documents may come from teaching and research institutions in France or abroad, or from public or private research centers.
L'archive ouverte pluridisciplinaire HAL, est destinée au dépôt et à la diffusion de documents scientifiques de niveau recherche, publiés ou non, émanant des établissements d'enseignement et de recherche français ou étrangers, des laboratoires publics ou privés. 


\title{
Caldera rim collapse: A hidden volcanic hazard
}

\author{
Olivier Merle $^{\mathrm{a}, *}$, Laurent Michon ${ }^{\mathrm{b}}$, Patrick Bachèlery ${ }^{\mathrm{b}}$ \\ a Laboratoire Magmas et Volcans UMR 6524, CNRS-IRD-Université Blaise Pascal, 5 rue Kessler 63038 Clermont-Ferrand, France \\ b Laboratoire GéoSciences Réunion, Université de La Réunion, Institut de Physique du Globe de Paris, CNRS-UMR 7154, Géologie des Systèmes Volcaniques, \\ 15 avenue René Cassin 97715 Saint Denis de La Réunion, France
}

\begin{abstract}
A B S T R A C T
Following the emblematic flank collapse of Mount St Helens in 1981, numerous models of flank sliding have been proposed. These models have allowed to largely improve the understanding of mechanisms involved in such landslides, which represent a tremendous risk for populations living around volcanoes. In this article, a new mode of landslide formation, related to buried calderas, is described. The model emphasizes the paramount importance of the hidden ring fault that, even when the caldera is buried, still remains a plane of weakness in the core of the edifice. Under certain conditions, this plane of weakness becomes activated as the upper part of a pre-existing critical slip surface and is used in the emplacement of huge landslides which travel downslope at a very high velocity. A natural example is taken from Piton de la Fournaise Volcano (La Réunion Island, Indian Ocean). It reveals that the primary cause triggering caldera rim collapse is partial unbuttressing of the flank of the volcano. In the natural example, this occurs through regressive erosion that excavates deep canyon in the direction of the buried caldera but other mechanisms may exist. On account of the large volumes of material involved in caldera rim collapse as well as their long runout distances, such a volcanic hazard should be taken into account on every volcano where buried calderas are suspected.
\end{abstract}

\section{Introduction}

Flank landslide is one of the most important hazard that can happen in volcanic terranes. The scientific community became aware of the devastating effect of such landslides when the Mount St Helens erupted on May 18, 1980 (Lipman and Mullineaux, 1981). A catastrophic collapse of part of the edifice preceded the eruption and the landslide travelled at a velocity of about $200 \mathrm{~km} / \mathrm{h}$ over a distance of about $25 \mathrm{~km}$. To face such cataclysmic events, there is no way to protect civilians but to evacuate the entire population from the area at risk before the collapse occurs (McGuire, 2003).

This emblematic eruption has been the starting point of numerous studies on this volcanic hazard, which has been shown since then to be a common feature worldwide (e.g. Siebert, 1984). Theses studies have allowed making great progress in the understanding of the triggering factors of flank landslide. For instance, triggering factors include dyke or magma emplacement (e.g. Voight et al., 1981; Dieterich, 1988; McGuire et al., 1990; Delaney et al., 1998; Tibaldi, 2001), earthquakes (e.g. Ando, 1979; Montaldo et al. 1996), a weak decollement horizon within the edifice (e.g. Merle and Lénat, 2003; Oehler et al. 2005), excess pore pressures due to intrusion (e.g. Voight and Elsworth, 1997; Elsworth and Day, 1999), regional faulting (e.g. Hall et al., 1999; Ventura et al., 1999; Merle et al. 2001), cryptodome emplacement (e.g. Donnadieu et al., 2001), volcano spreading (van

\footnotetext{
* Corresponding author. Tel.: +262 2623499 94; fax: +262 262938266.

E-mail address: Merle@opgc.univ-bpclermont.fr (O. Merle).
}

Wyk de Vries and Francis, 1997), changing sea levels (Firth et al., 1996) and hydrothermal alteration (e.g. López and Williams, 1993; van Wyk de Vries et al., 2000; Reid et al., 2001). As suggested by Acocella (2005), several factors may act simultaneously to trigger lateral collapse and hybrid mechanisms may be common.

The aim of this article is to present a new mode of landslide formation in volcanic terranes which, to our knowledge, has never been described so far. These collapses may happen in volcanoes that have developed one or several calderas. Caldera infilling by lava flows makes sometimes these structures difficult to be identified in the field, especially when younger and smaller calderas have formed around the main eruptive centre. This is particularly true for large volcanic edifices that have eruptive stories that last more than several hundred thousand years. For example, in oceanic shield volcanoes as Piton de La Fournaise in La Réunion Island (Indian Ocean), nested calderas are partially hidden by following eruptions, active erosion and tropical vegetations that cover old parts of the edifice so that, even when old calderas are suspected, it may be impossible to map along one or multiples ring faults with accuracy. However, such calderas exist and the ring fault is a plane of weakness that may originate catastrophic failure and collapse representing a serious risk for populations living in the vicinity of the potential landslides.

\section{Caldera rim collapse}

The formation of a caldera is classically ascribed to the vertical collapse of the overlying roof during emptying of a shallow magma 
chamber (e.g. Lipman, 1984). This vertical collapse occurs along a ring fault system and leaves a vast, circular and flat-lying depression limited by sub-vertical cliffs that can reach several hundred meters high (Fig. 1a). The size of a caldera is variable and ranges from a few kilometres to several tens of kilometres in width (e.g. Lipman, 2000). The whole structure is generally considered to be stable, except recurrent rock fall along the sub-vertical cliffs.

However, it has already been advocated that stress concentrations develop around the caldera once the vertical collapse is achieved (Gudmundsson, 1988, Marti et al. 1997; Hürlimann et al., 2000). This may trigger large-scale destabilization of the flank along a gliding horizon as proposed for the Icod and La Oratova landslides which have broken up part of the ring fault of La Canadas caldera in Tenerife (Marti et al. 1997; Hürlimann et al., 2000).

Such a lateral escape may indeed happen following caldera collapse but the depression is generally filled by subsequent lava flows coming from the main eruptive centre located in the caldera. Caldera infilling is a slow process during which successive lava flows come to abut against the cliff of the ring fault. When the filling up comes to completion, lava flows swamped the caldera overflowing its rim (Fig. 1b). Then, the ring fault becomes buried and hidden under lava flows and may be undetectable by field studies. When this happens and in the lack of erosion, only geophysical studies like gravimetry, self-potential or high-resolution electrical resistivity tomography may sometimes reveal caldera boundaries (e.g. Tort and Finizola, 2005). Lavas within the caldera exhibit a tabular structure, which is welded along the ring fault to the generally gently sloping lavas and ash deposits of the external flank. In contrast, overflowing lavas dip according to the flank slopes.

Such a configuration is not considered to be prone to destabilisation. The hidden ring fault, however, is a near-vertical fault and remains a plane of weakness in the core of the edifice. As long as this fault is laterally buttressed by the flank of the volcano, there is no risk that it can be re-activated, except for a new episode of vertical caldera collapse due to the magmatic evolution of the volcano. Hazard may come from a drastic reduction of lateral confinement and this may happen if, for some reasons, the buttress is removed.

Erosion is a good candidate to slowly remove the lateral buttress that prevents the destabilisation to occur. Regressive erosion through a valley is common in volcanoes once a lateral sector is no longer covered by fresh lavas or volcanoclastic deposits. When the head of the valley is close enough to the rim of the caldera, catastrophic lateral collapse may occur taking away the flank of the volcano and leaving instead a spectacular vertical cliff, which is the limit of the tabular structure of the caldera infilling (Fig. 1c).

Failure occurs along a critical slip surface which looks like a broken line. The upper part of the slip surface follows the sub-vertical ring fault whereas inclined lavas and volcanic deposits of the external flank are suitable levels for the lower part (Fig. 1d). The driving force of the lateral collapse is gravity but several local factors may trigger the instability like pore fluid pressure, a decollement horizon within the volcanoclastic products of the flank as well as the outward inclination

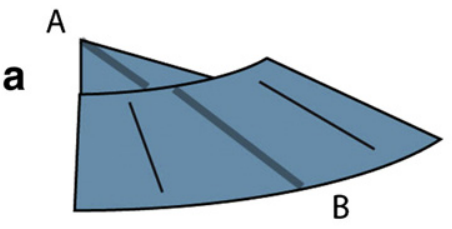

b

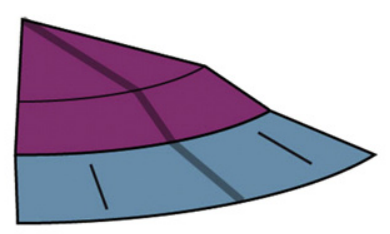

C

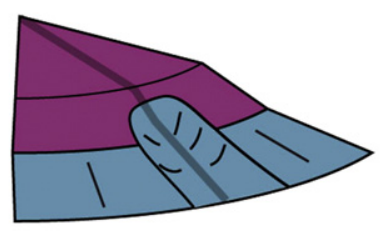

d
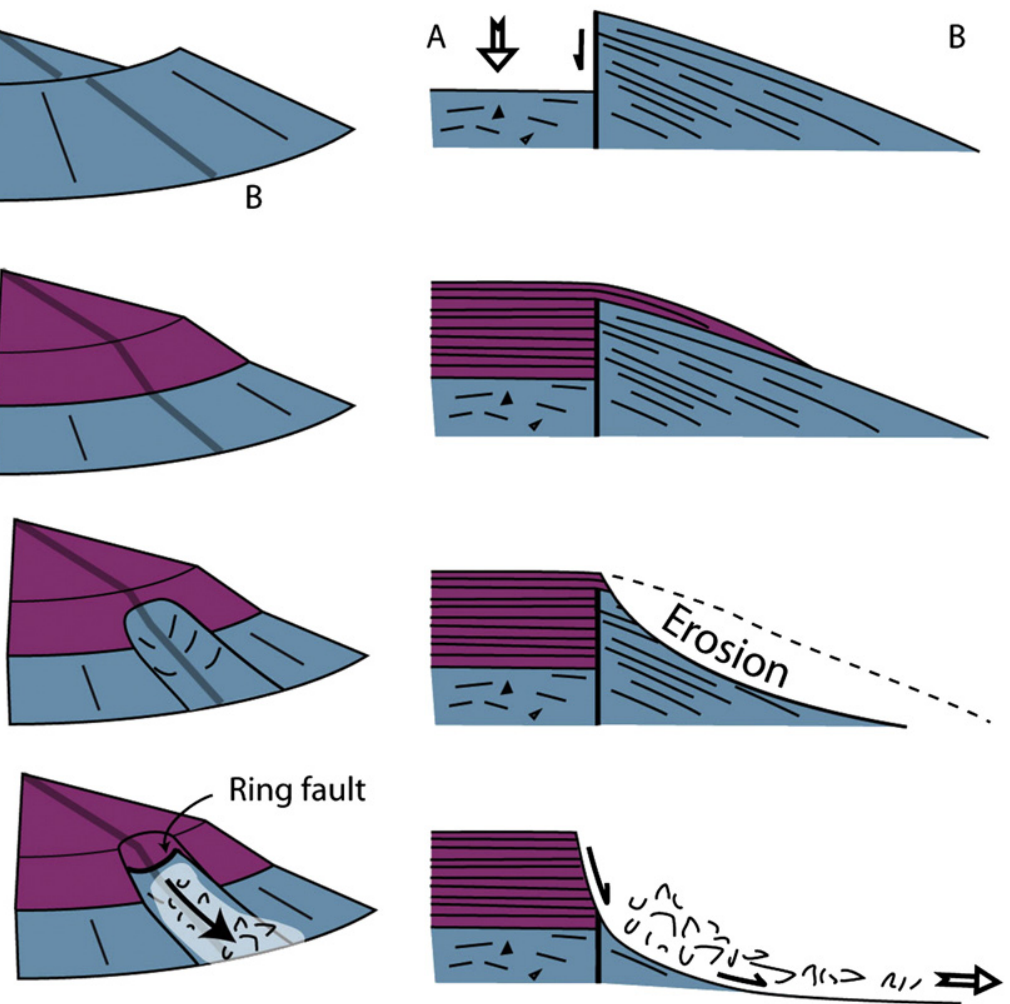

e

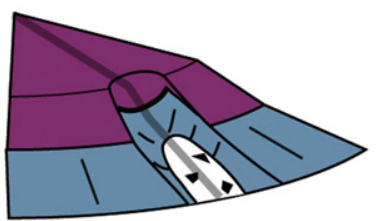

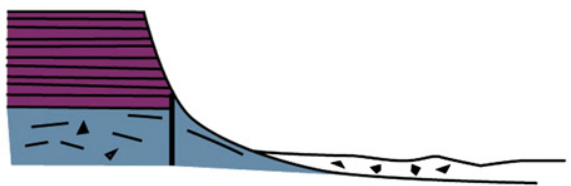

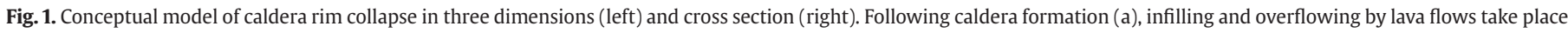

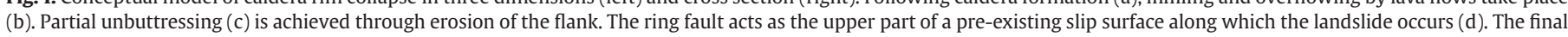
stage (e) displays a spectacular cliff which is the tabular lava stacking resulting from the previous infilling stage. 
of those, earthquakes, rock alteration, etc. For instance, it has been shown that the ring fault of a caldera is a highly permeability plane that preferentially drains fluids (e.g. Lénat et al. 1998; Finizola et al., 2002), which promotes pore fluid pressure and rock alteration. The key point of the model is that these local factors are unable to trigger the landslide without previous unbuttressing.

Weak lateral confinement of the caldera wall may be achieved by erosion as proposed herein but other mechanisms like downslope flank sliding may also occur. In this case, a limited downward landslide may be the precursor of a larger and dramatic caldera rim collapse. Also, it is known that inward, vertical or outward dipping ring faults may develop during caldera collapse (e.g. Roche et al., 2000, Acocella, 2007). This is likely to play a role in the process under consideration, as outward dipping faults exhibit orientations that favour the caldera rim collapse whereas inward faults may delay or even prevent it.

The successive stages of the process can be summarized as follows: 1) caldera formation 2 ) caldera infilling 3 ) unbuttressing and 4) caldera rim collapse. Such an evolution is not related to the initial slope of the volcano and may happen to both strato-volcanoes and shield volcanoes, once a caldera has been buried by subsequent lava flows. Then, the model may be applied to any type of volcano.

\section{The Mahavel landslide}

A clear and striking illustration of the model may be found at Piton de la Fournaise volcano on La Réunion Island. Resulting from a mantle hot spot, La Réunion Island is one of the largest basaltic shield volcano on Earth exhibiting a total thickness of about $7000 \mathrm{~m}$ from the oceanic floor to the highest summits, which reach $3000 \mathrm{~m}$ high. It is constituted of two juxtaposed volcanic massifs: Piton des Neiges which is dormant for about $12 \mathrm{ka}$ (Deniel et al., 1992) and Piton de La Fournaise which is highly active for about $530 \mathrm{ka}$ (Gillot et al., 1990).

Piton de la Fournaise activity was characterised by the formation of very large nested calderas whose sizes may be correlated with ages (Bachèlery, 1981; Bachèlery and Mairine, 1990, Mairine and Bachèlery, 1997) (Fig. 2). Classifying according to age and size, one may define
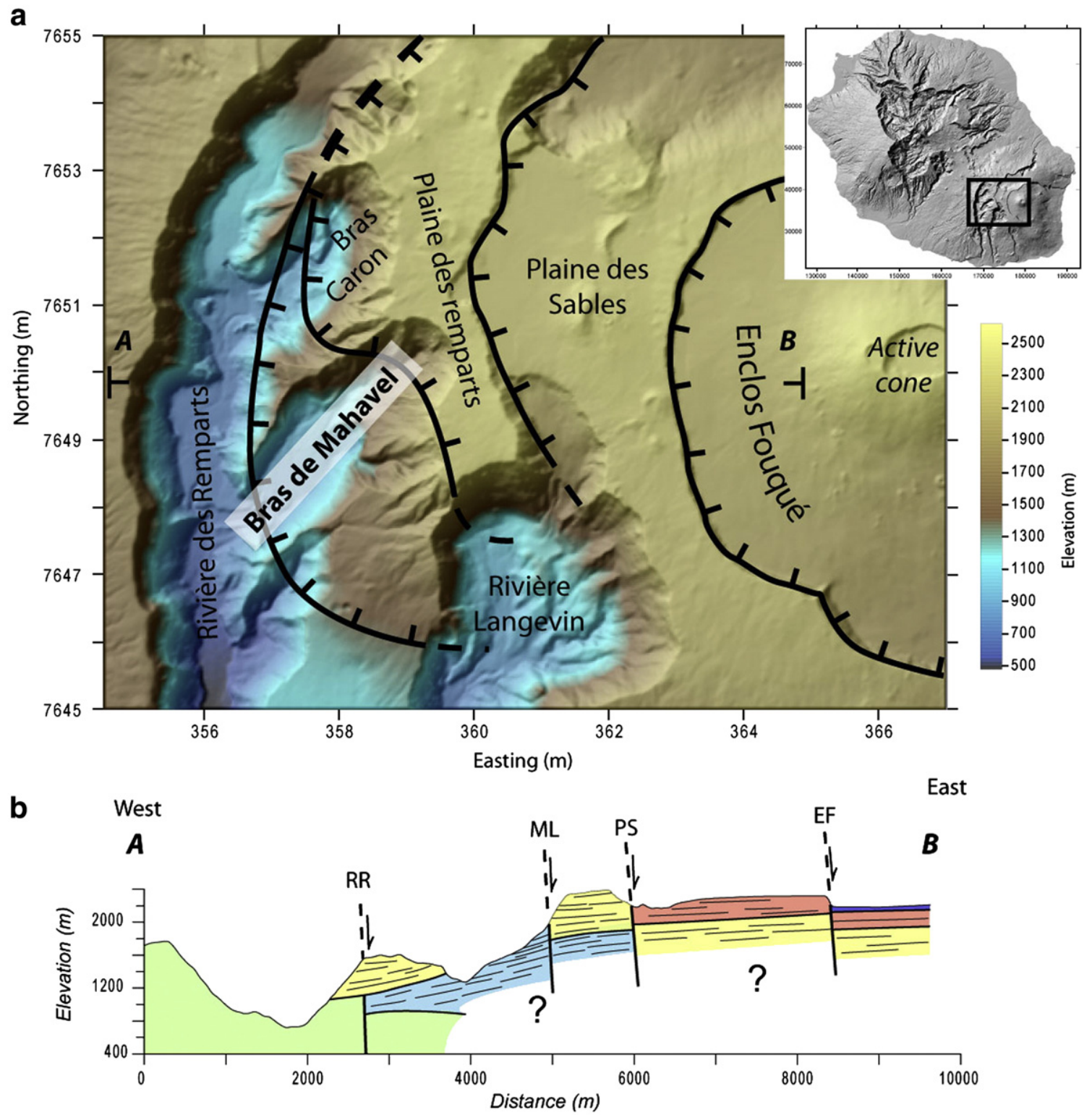

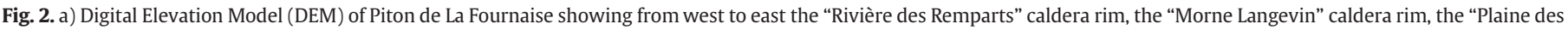

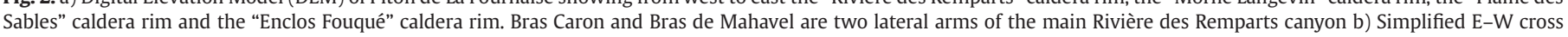

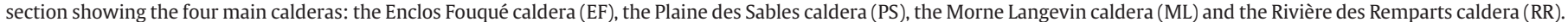




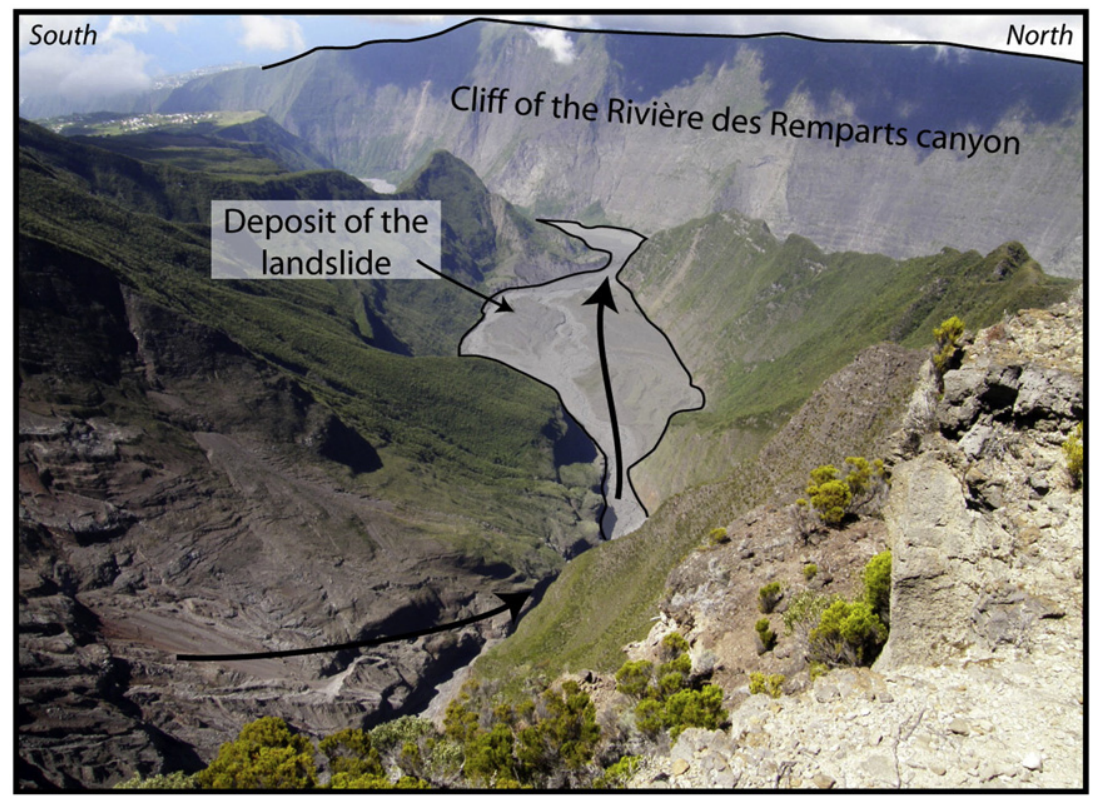

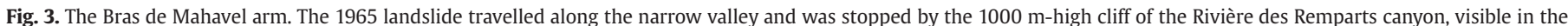
background.

"Rivière des Remparts" caldera, the "Morne Langevin" caldera, the "Plaine des Sables" caldera and the "Enclos Fouqué" caldera. The present-day active volcanic centre is located within the smallest "Enclos Fouqué" caldera (Fig. 2).

The 150 ka "Morne Langevin" caldera is a buried caldera, the limit of which is nearly impossible to map with accuracy in the field. The tabular Morne Langevin lavas have entirely filled up the caldera and, overflowing its rim, have flowed down westward onto the old series, called the Mahavel formation, which is dipping south-west at $15-20^{\circ}$. Nowadays, Intense regressive erosion has excavated a spectacular arcuate canyon, the Rivière des Rempart canyon, limited to the west by a vertical cliff of more than $1000 \mathrm{~m}$ high (Fig. 2).

When looking at the north-south Rivière des Remparts canyon, it can be seen that the regressive erosion has created two NE-SW oriented arms, the Bras Caron and Bras de Mahavel arms that have propagated in direction of the Morne Langevin caldera (Fig. 2). As classically reported on Piton de la Fournaise massif, the head of the valley is a very steeply dipping cliff, reaching about $1000 \mathrm{~m}$ high. This regressive erosion has progressively diminished the lateral confinement of the caldera rim, leading to conditions suitable for a major instability.

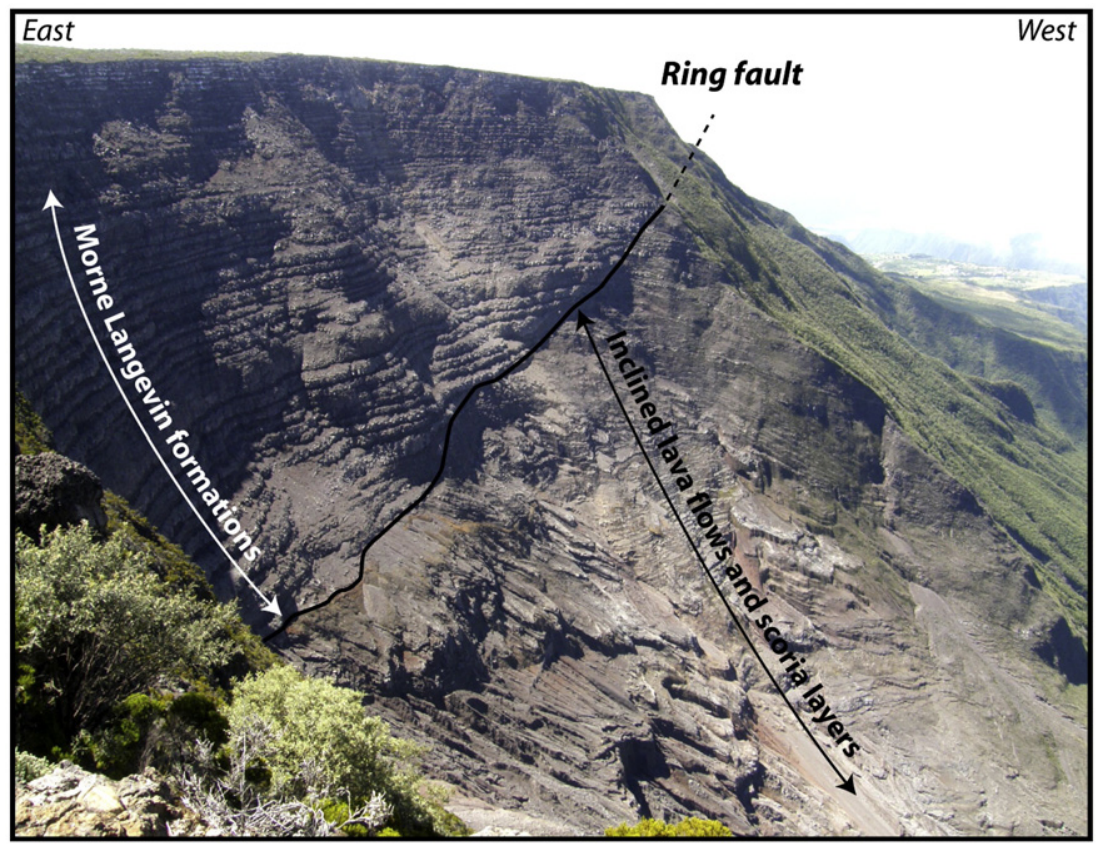

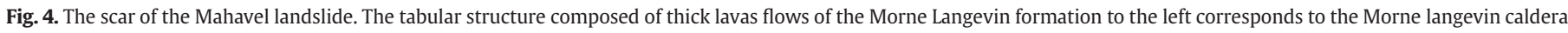

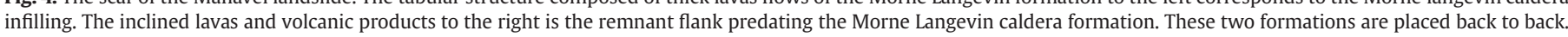
Solid line shows the trace of the ring fault in between. 
At 3 am on 6th may 1965, the catastrophic and unpredicted event occurred. In a few minutes, a large portion of the cliff collapsed and a huge mass of dislocated materials was channelled in the Mahavel arm, travelled along $6 \mathrm{~km}$ at a very high velocity, and came to abut against the north-south oriented Rivière des Rempart cliff, which stopped it (Fig. 3). In its course, the initial debris avalanche was progressively transformed into debris flow or lahar as a result of abundant surface water. The volume of transported materials was estimated to be in the range from 0.03 to $0.05 \mathrm{~km}^{3}$ (Stieltjes, 1990). This volume may be usefully compared to the total volume of about $0.02-0.03 \mathrm{~km}^{3}$ involved in two landslides occurring within a time separation of $7 \mathrm{~min}$ at Stromboli volcano. Both landslides set tsunami waves in motion that hit the coast of Stromboli causing severe damage to buildings and structures (Bonaccorso et al., 2003; Tinti et al., 2006). The tsunamis were also observed in a wide area around Stromboli along the northern Silicy and Tyrrhenian coasts as well as all over the Aeolian archipelago causing damage on other islands (Bonaccorso et al., 2003; Tinti et al., 2006).

Due to the nearly uninhabited area and the night event, there were no casualties. However, the slide resulted in a natural dam that obstructed the Rivière des Rempart canyon over its entire width (i.e. $450 \mathrm{~m}$ ). Then, in a few months, upper waters formed a lake on an area of about $3 \times 10^{5} \mathrm{~m}^{2}$ and reaching a depth of about $30 \mathrm{~m}$. This represented a very serious threat for the St Joseph city located $12 \mathrm{~km}$ downstream. To avoid the brutal bursting of the dam and a dramatic flood over the city, a channel was excavated to allow the emptying of the lake and a free circulation of running waters.

The cause of the landslide was attributed to several factors including a very rainy period preceding the collapse, the inclined strata of the Mahavel formation and rock alteration. Although these local factors have certainly contributed to the setting in motion of the landslide, careful examination of the scar reveals that these cannot be considered as the primary cause of the event. The scar is an out-ofthe-way place for field studies due to permanent rock fall and crumbling which makes the area very dangerous. However, it is wellvisible from the top owing to an advance of the cliff (Fig. 4). The upper part of the scar is constituted by the tabular formation of the Morne langevin. At the bottom, inclined strata of the Mahavel formation can be seen. These are clearly backed on to the thick lava flows of the Morne langevin. This interpretation is consistent with the observation of the small transverse cliff, which constitutes the lateral limit of the landslide (Fig. 4). There, the near-vertical contact between the alternance of thin lava flows and fall deposits of the Mahavel formation and the thick lava flows of the Morne Langevin formation is especially well-visible. In other words, the Mahavel landslide has brought the buried Morne Langevin caldera ring fault to light and this is the only place where it can be traced out without any doubt, as exemplified by the dense vegetation visible in the background beyond the transverse scar of the landslide (Fig. 4).

This allows a re-interpretation of the Mahavel landslide in terms of caldera rim collapse. The regressive erosion along the Bras de Mahavel arm led to the unbuttressing of the caldera rim and to the re-activation of the plane of weakness that constitutes the ring fault. Along the ring fault, gravity has pulled off and detached the upper part of the Mahavel formation from the tabular Morne Langevin formation, the multiple inclined strata of the Mahavel formation acting as basal sliding planes for the landslide. In the lack of the ring fault which can be considered as the upper part of a pre-existing slip surface, such a huge catastrophic landslide would not have been possible.

\section{Conclusion}

It has been shown that caldera rim collapse is an important volcanic hazard, which may represent a serious risk causing disaster and casualties if occurring in densely inhabited areas. Such a process may trigger huge gravity-driven mass-transfer over several $10 \mathrm{~km}$ involving several tens of millions cubic metres of material. The natural example taken from Piton de La Fournaise volcano is a large debris avalanche which clearly demonstrates that this volcanic hazard has been underestimated so far. A good evaluation of the volcanic hazard and risk implies the search for this type of structure on all volcanoes that can conceal calderas infilled by lava flows.

Monitoring volcanoes to measure ground deformation with, for instance, geodetic data or highly sophisticated techniques like interferometry radar (SAR), are likely to forecast the timing of eventual collapses. However, it is sometimes hard to make a decision about which part of a volcano should be monitored as potential hazards may be difficult to assess. To this respect, caldera rim collapse reveals that classic and careful field studies remain an invaluable toll to identify hazard, especially in the case of buried calderas. Where buried calderas are suspected, field studies should provide a map where principal hazard and risk are clearly identified around the hidden ring fault, which in turn allows efficient monitoring and successful forecasting.

\section{Acknowledgments}

This research has been funded by the French ANR project VOLCARISK (contract 06-CATT-013-04). We thank Valerio Acocella and Adelina Geyer for their constructive reviews of the manuscript.

\section{References}

Acocella, V., 2005. Modes of sector collapse of volcanic cones: insights from analogue experiments. Journal of Geophysical Research 110, B02205. doi:10.1029/ 2004JB003166.

Acocella, V., 2007. Understanding caldera structure and development : an overview of analogue models compared to natural examples. Earth-Sciences Review 85, $125-160$.

Ando, M., 1979. The Hawaii earthquake of November 29, 1975: low dip angle faulting due to forceful injection of magma. Journal of Geophysical Research 84, 7616-7626.

Bachèlery, P., 1981. Le Piton de la Fournaise (Ile de la Réunion). Etude volcanologique, structurale et pétrologique. PhD thesis, University of Clermont-Ferrand, ClermontFerrand, 215p.

Bachèlery, P., Mairine, P., 1990. Evolution volcano-structurale du Piton de la Fournaise depuis $0.53 \mathrm{Ma}$. In: Lénat, J.-F. (Ed.), Le volcanisme de la Réunion - Monographie: Centre de Recherche en Volcanologie. Clermont-Ferrand, France, pp. 213-242.

Bonaccorso, A., Calvari, S., Lodato, L., Patanè, D., 2003. Dynamics of the December 2002 flank failure and tsunami at Stromoboli volcano inferred by volcanological and geophysical observations. Geophysical Research Letters 30 10.1029/2003GL017702.

Delaney, P.T., Denliger, R.P., Lisowsky, M., Miklius, A., Okubo, P.G., Okamura, A.T., Sako, M.K., 1998. Volcanic spreading at Kilauea, 1976-1996. Journal of Geophysical Research 103, 18003-18023.

Deniel, C., Kieffer, G., Lecointre, J., 1992. New ${ }^{230} \mathrm{TH}$ and ${ }^{238} \mathrm{U} 14 \mathrm{C}$ age determinations from Piton des Neiges volcano, Réunion: a revised chronology for the differentiated series. Journal of Volcanology and Geothermal Research 51, 253-267.

Dieterich, J.H., 1988. Growth and persistence of Hawaiian volcanic rift zones. Journal of Geophysical Research 12, 147-160.

Donnadieu, F., Merle, O., Besson, J.L., 2001. Volcanic edifice stability during cryptodome intrusion. Bulletin of Volcanology 63, 61-72.

Elsworth, D., Day, S., 1999. Flank collapse triggered by intrusion: the Canarian and Cape Verde Archipelagoes. Journal of Volcanology and Geothermal Research 94, 323-340.

Finizola, A., Sortino, F., Lénat, J.-F., Valenza, M., 2002. Fluid circulation at Stromboli volcano (Aeolian Islands, Italy) from self potential and $\mathrm{CO}_{2}$ surveys. Journal of Volcanology and Geothermal Research 116, 1-18.

Firth, C., Stewart, L., McGuire, W.J., Kershaw, S., Vita-Finzi, C., 1996. Coastal elevation changes in eastern Silicy: implications foe volcano instability at Mount Etna. In: McGuire, W.J. (Ed.), Volcano Instability on the Earth and other Planets: Geological Society of London Special Publication, vol. 110, pp. 153-167.

Gudmundsson, A., 1988. Formation of collapse calderas. Geology 16, 808-810.

Gillot, P.-Y., Nativel, P.E., Condomines, M., 1990. Géochronologie du Piton de la Fournaise. In: Lénat, J.-F. (Ed.), Le volcanisme de la Réunion - Monographie: Centre de Recherche en Volcanologie. Clermont-Ferrand, France, pp. 243-256.

Hall, M.L., Robin, C., Beate, B., Mothes, P., Monzier, M., 1999. Tungurahua volcano, Ecuador: structure, eruptive history and hazards. Journal of Volcanology and Geothermal Research 91,1-21.

Hürlimann, M.N., Marti, J., Ledesma, A., 2000. Mechanical relationship between catastrophic volcanic landslides and caldera collapses. Geophysical Research Letters 27, 2393-2396.

Lénat, J.-F., Robineau, B., Durand, S., Bachèlery, P., 1998. Etude de la zone sommitale du volcan Karthala (Grande Comore) par polarisation spontanée. Comptes Rendus de l'Académie des Sciences 327, 781-788. 
Lipman, P.W., 1984. The roots of ash flow calderas in western North America: windows into the tops of granitic batholiths. Journal of Geophysical Research 89, 8801-8841.

Lipman, P.W., 2000. Calderas. In: Sigurdsson, H. (Ed.), Encyclopedia of Volcanoes. Academic Press, San Francisco, pp. 643-662.

Lipman, P.W., Mullineaux, D., 1981. The 1980 eruptions of Mount St Helens: US Geological Survey Professional Paper, 1250.

López, D.L., Williams, S.N., 1993. Catastrophic volcanic collapse: relation to hydrothermal processes. Science, 260, 1794-1796.

Mairine, P., Bachèlery, P., 1997. Major erosional period in the building of Piton de la Fournaise (Réunion Island). Comptes Rendus de l'Académie des Sciences 325, 243-249.

Marti, J., Hürlimann, M., Ablay, G.J., Gudmundsson, A., 1997. Vertical and lateral collapse on Tenerife (Canary islands) and other volcanic ocean islands. Geology 25, 879-882.

McGuire, W.J., 2003. Volcano instability and lateral collapse. Revista 1, 33-45.

McGuire, W.J., Pullen, A.D., Saunders, S.J., 1990. Recent dyke-induced large-scale block movement at Mount Etna and potential slope failure. Nature 343, 357-359.

Merle, O., Lénat, J.F., 2003. Hybrid collapse mechanism at Piton de la Fournaise volcano, Réunion Island, Indian Ocean. Journal of Geophysical Research 108 (NO. B3), 2166. doi:10.1029/2002JB002014.

Merle, O., Vidal, N., van Wyk de Vries, B., 2001. Experiments on vertical basement fault reactivations below volcanoes. Journal of Geophysical of Research 106, 2153-2162.

Montaldo, A., Vicinguerra, S., Menza, S., Patane, G., 1996. Recent seismicity of Mount Etna : implications for flank instability. In: McGuire, W.J. (Ed.), Volcano Instability on the Earth and other Planets. Geological Society of London Special Publication, vol. 110, pp. 169-177.

Oehler, J.F., van Wyk de Vries, B., Labazuy, P., 2005. Landslides and spreading of oceanic hot-spot and arc shield volcanoes on Low Strength Layers (LSLs): an analogue modelling approach. Journal of Volcanology and Geothermal Research 144 169-189.

Reid, M.E., Sisson, T.W., Brien, D.L., 2001. Volcano collapse promoted by hydrothermal alteration and edifice shape, Mount Rainier, Washington. Geology 29, 779-782.
Roche, O., Druitt, T.H., Merle, O., 2000. Experimental study of caldera formation. Journal of Geophysical and Geothermal Research 105, 395-416.

Siebert, L., 1984. Large volcanic debris avalanches: characteristics of source areas, deposits and associated eruptions. Journal of Volcanology and Geothermal Research 22, 163-197.

Stieltjes, L., 1990. Evaluation des risques naturels au Piton de La Fournaise. In: Lénat, J.-F. (Ed.), Le volcanisme de la Réunion - Monographie. Centre de Recherche en Volcanologie, Clermont-Ferrand, pp. 357-379.

Tibaldi, A., 2001. Multiple sector collapses at Stromboli volcano, Italy : how they work. Bulletin of Volcanology 63, 112-125.

Tinti, S., Maramai, A., Armigliato, A., Graziani, L., Manucci, A., Pagnoni, G., Zaniboni, F., 2006. Observations of physical effects from tsunamis of December 30, 2002 at Stromboli volcano, southern Italy. Bulletin of Volcanology 68, 450-461.

Tort, A., Finizola, A., 2005. The buried caldera of Misti volcano, Peru, revealed by combining a self-potential survey with elliptic Fourier function analysis of topography. Journal of Volcanology and Geothermal Research 141, 283-297.

van Wyk de Vries, B., Francis, P., 1997. Catastrophic collapse at stratovolcanoes induced by gradual volcano spreading. Nature 387, 387-390.

van Wyk de Vries, B., Kerle, N., Petley, D., 2000. Sector collapse forming at Casita volcano, Nicaragua. Geology 28, 167-170.

Ventura, G., Vilardo, G., Bruno, P.P., 1999. The role of flank failure in modifying the shallow plumbing system of volcanoes : an example from Somma-Vesuvius, Italy. Geophysical Research Letters 26, 3681-3684.

Voight, B., Elsworth, D., 1997. Failure of volcano slope. Géotechnique 47, 1-31.

Voight, B., Glicken, H., Janda, J., Douglas, P.M., 1981. Catastrophic rockslide avalanche of may 18, in the 1980 Eruptions of Mount St Helens, Washington. In: Lipman, P.W., Mullineaux, D.R. (Eds.), U S Geological Survey Professional Paper, vol. 125, pp. 347-377. 